Marquette University

e-Publications@Marquette

College of Communication Faculty Research and

Publications

Communication, College of

$1-1-2011$

Domestic Violence in Men's and Women's

Magazines: Women Are Guilty of Choosing the Wrong Men, Men Are Not Guilty of Hitting Women

Pamela Hill Nettleton

Marquette University, pamela.nettleton@marquette.edu

Accepted version. Women's Studies in Communication, Vol. 34, No. 2 (2011): 139-160. DOI. (C) 2011

Taylor \& Francis (Routledge). Used with permission. 


\title{
Domestic Violence in Men's and Women's Magazines: Women Are Guilty of Choosing the Wrong Men, Men Are Not Guilty of Hitting Women
}

\author{
Pamela Hill Nettleton \\ Diederich College of Communication, Marquette University \\ Milwaukee, WI
}

\begin{abstract}
Men's and women's magazine discourse on domestic violence characterizes women as guilty of choosing the wrong men but does not hold men responsible for hitting women. Using qualitative narrative analysis on 10 leading titles over 10 years, I find an ongoing tolerance for and celebration of domestic violence in men's magazines and an enduring expectation in women's that women bear responsibility for both genders. No magazines discuss patriarchal cultural structures that enable violence against women.
\end{abstract}

Often, the most dangerous man in a woman's life is the one who says he loves her. In the United States, if a woman is beaten, raped, or murdered, it will likely be by her husband or boyfriend. Popular magazines are an important source of public information about relationships and relationship violence, yet the discourse around domestic violence is unbalanced: women's magazines hold women responsible for the violence men do, and men's magazines sidestep male responsibility and make light of physical violence at home. Neither type of magazine takes on the patriarchal cultural structures that support and enable the existence of violence against women. This study examines this issue in an analysis of domestic violence

Women's Studies in Communication, Vol. 34, No. 2 (2011): pg. 139-160. DOI. This article is (C) Taylor \& Francis (Routledge) and permission has been granted for this version to appear in e-Publications@Marquette. Taylor \& Francis (Routledge) does not grant permission for this article to be further copied/distributed or hosted elsewhere without the express permission from Taylor \& Francis (Routledge). 
NOT THE PUBLISHED VERSION; this is the author's final, peer-reviewed manuscript. The published version may be accessed by following the link in the citation at the bottom of the page.

narratives in 10 popular men's and women's magazines from 1998 to 2008.

\section{What This Study Does}

Scholarly exploration of how popular magazines portray domestic violence exists but is limited, and there is even less investigation of domestic violence representations among magazines aimed specifically at men. In a qualitative narrative analysis of both men's and women's magazines over a recent 10 -year period, I examine domestic violence coverage aimed at men and at women. I situate this work within the body of feminist media studies of violence against women and within the cultural studies perspective of Stuart Hall's theories of representation and of the power of the absent representation $(1975,1988,1992)$. I identify four central themes of domestic violence representation:

1. Women are responsible for preventing the violence of men and men cannot help themselves.

2. Domestic violence is terrifying to women and amusing to men.

3. Statistics are distorted to implicate men and overlook the violence of women.

4. The only way to prevent domestic violence is to separate victims from abusers (and it is the victim's responsibility to do this).

I also identify four key absences-narratives that do not appear in magazine discourse:

1. No magazines hold men responsible for their violence.

2. None suggests that men should take active roles in reducing domestic violence.

3. No narratives represent victims as innocent of the violence done to them.

4. No connection is drawn or discussed between patriarchal social structures and the existence of domestic violence.

This work relies particularly upon two earlier studies by sociologist Nancy Berns. Berns made separate studies of women's (1999) and then men's (2001) magazines from earlier time periods1970 through 1997 and 1970 through 1999, respectively-and more will be said about her findings (1999, 2001, 2004). My study differs 
from those of Berns in that I include both men's and women's magazines in the same study, comparing their messages, and my 10year sample of texts begins in the year that Berns's surveys conclude.

My study addresses these research questions:

1. How does men's magazine coverage of domestic violence differ from women's magazine coverage?

2. How does that coverage characterize culpability and cause?

3. What characterizations and representations are absent, and what might those absences mean?

Before turning to the analysis, I begin by outlining the problem of domestic violence, reviewing some of the previous literature on the topic, and identifying the theoretical frame that guides this study.

\section{The Problem of Domestic Violence and Why It Matters}

This section presents statistics about the prevalence of domestic violence, the frequency of its occurrence, its effects on the lives of children raised with it, and the financial costs arising from it, in an effort to demonstrate some of the cultural effects of domestic violence and to support an argument of why magazine coverage of the issue matters. In the United States, domestic violence affects 1.3 million women annually (Tjaden \& Thoennes, 2000a). Almost one in four women have been killed or beaten by a partner (Tjaden \& Thoennes, 2000b); more than one in three women in the United States have been sexually coerced by a partner (Basile, 2002). Most stalkers are or have been intimate partners, and most women stalked are eventually attacked or killed by their stalker (McFarlane et al., 1999; Tjaden \& Thoennes, 1998). Sexual violence victims are almost always women. Men commit $100 \%$ of the rapes, $92 \%$ of the physical assaults, and $97 \%$ of the stalking acts against women; they also commit $70 \%$ of the rapes, $86 \%$ of the physical assaults, and $65 \%$ of the stalking acts against other men (Tjaden \& Thoennes, 2000a). Men with male partners have a higher incidence of being raped, assaulted, or stalked than do men with female partners (Tjaden, 2001). The damage of domestic violence extends beyond women to hurting family members, even those who are not battered, and sows the seeds of future 
violence. An estimated 3.3 million to 10 million U.S. children witness domestic violence each year, negatively affecting the development of many of them (Lawrence, 2002). Children exposed to domestic violence suffer post-traumatic stress disorder (PTSD) symptoms, such as bed-wetting, and have an increased risk of health problems, such as allergies, asthma, and gastrointestinal problems (Graham-Bermann \& Seng, 2005). Exposure to violence at home is a significant factor in predicting a child's future violent behavior (Singer, Miller, Guo, Slovak, \& Frierson, 1998), and exposure to maternal intimate partner violence leads to serious behavioral problems (Kernic et al., 2003). Domestic violence is costly to families, the health care system, the justice system, and the nation. Abused women use \$1,775 more health services annually than do nonabused women (Wisner, Gilmer, Saltzman, \& Zink, 1999), an annual national cost of $\$ 856.3$ million (Miller, Cohen, \& Wiersema, 1996). Crime costs Americans $\$ 450$ billion annually, $\$ 67$ billion of that due to domestic violence (Miller et al., 1996). Although enormous in their own right, these health care statistics no doubt fall short of reality; they are drawn only from women who report domestic violence. Most women-92\%-do not (Caralis \& Musialowski, 1997; Friedman, Samet, Roberts, Hudlin, \& Hans, 1992; McCauley, Yurk, Jenckes, \& Ford, 1998; Rodriguez, Quiroga, \& Bauer, 1996). Although their effects on the lives of women and children-and its costs to the nation-are substantial, domestic abusers get lighter legal punishment than do others who assault. When non-family members assault women, $77 \%$ of them are sent to prison; when family members assault women, only $45 \%$ are incarcerated (Durose et al., 2005). Correction efforts with male batterers are largely unsuccessful, and most prevention efforts are aimed at changing the behavior of the victim, not the perpetrator (Durose et al., 2005; Gondolf, 2000; Jewkes, 2002; Puffet \& Gavin, 2004). Even when batterers are referred into antiviolence and anger management programs by the court, many drop out (Jewkes, 2002), reoffend within six months (Gondolf, 2000), and are rearrested on similar charges within two years (Puffett \& Gavin, 2004).

One prevention program trains medical professionals to ask female patients if they feel safe at home (Jewkes, 2002) but does not ask male patients if they are violent at home. Emergency housing and hotline support are aimed at female victims, but this study found none 
for male perpetrators. Although there is recognition within some domestic violence programs that "violence is an expression of cultural values, rather than simply individual pathology, and reflects important tensions in the social structure" (Indermaur, Atkinson, \& Blagg, 1998, p. 2), fund-raising related to domestic violence focuses on building shelters for women and children and on supporting educational efforts aimed at women, rather than on shifting male or cultural attitudes. "However much the domestic violence revolution may have reformed the helping and justice professions, these changes are unlikely to endure unless the underlying cultural supports for domestic violence are displaced," write Stark and Buzawa (2009, p. xiiii).

The emotional, material, and physical costs of domestic violence are significant and troubling, and are sustained on both personal and public levels. The ways in which popular magazines represent domestic violence have a direct bearing on how individuals and the public perceive and respond to this issue and, consequently, on national attitudes and actions.

\section{Literature Review}

\section{Popular Media Make Culture}

Popular media do more than reflect social and cultural valuesmedia shape them. "Media texts do not present messages about our culture; they are culture," writes Rakow (2001, p. 42). Media messages are powerful, and their rhetoric is the terrain upon which hegemonic values are reinforced. Popular magazines are often gendered discourses, aimed at either women or men, yet regardless of intended audience, magazine narratives are predominantly patriarchal in nature. Before social and cultural change can occur, the role of popular media in disseminating patriarchal ideology must be recognized (Rakow, 2001). That is where "real social change takes place," argues Cuklanz (1996, p. 5).

\section{Feminist Media Studies of Magazines}

Women's magazine content plays a "socializing function" and shapes "society's sense of culture and our sense of self in culture" 
(Garner, Sterk, and Adams, 1998, p. 59). Ferguson (1983) calls women's magazines "agents of socialization" (p. 2) that disseminate a "cult of femininity" (p. 5). Class, race, and national boundaries are visible in that socializing function. Santa Cruz and Erazo (1980) conclude that media produced in industrialized countries do not reflect the concerns and issues of third-world women, and that political and economic interests are clearly at stake.

In Latin America, as in the United States, women have been moulded to consume goods and hold conservative political views. Women have, in fact, been a force which affirms existing cultural norms and holds back political change in many countries in the region. (Santa Cruz, 1995, pp. 52-53)

Popular magazines are dominated by portrayals of women as being primarily interested in beauty, fashion, and heterosexual romantic relationships (Duffy \& Gotcher, 1996; Evans, Rutberg, Sather, \& Turner, 1991; Ferguson, 1983; Garner et al., 1998; Hermes, 1995; McCracken, 1993; Peirce, 1990, 1995; Steiner, 1995; Wolf, 1992), including teen magazines, which are essentially focused on promoting heterosexual romance as the central project of a woman's life (Peirce, 1990; Schlenker, Caron, \& Halteman, 1998) and establishing men as the dominating force of romantic relationships (Carpenter, 1998; Durham, 1996, 1998; Garner et al., 1998). Duffy and Gotcher find that popularity and romance is emphasized to teens to a degree that creates a "distorted world view ....where success is determined by meeting the needs and expectations of males" (1996, p. 45). Garner and colleagues (1998) write, "Teenage girls' magazines sound the same themes sounded for years in women's magazines and home economics textbooks-how to meet successfully the needs and desires of men" (p. 74); men's magazine stories, however, are of "sexual conquest or of surviving demanding women" (p. 75).

Women's magazines move fluidly and contradictorily between supporting feminist ideas and arguing for the importance of physical beauty; between working toward self-fulfillment and pleasing others (McCracken, 1993). While magazines do offer genuinely helpful advice for women (Consalvo, 1997), they also offer powerful prescriptive reinforcement that the path to happiness is through a heterosexual relationship and purchasing beauty and fashion products (Durham, 
1996; McCracken, 1993; Merskin, 1999; Steiner, 1995; Weston \& Ruggiero, 1985-1986; Wolf, 1992). Janice Winship (1987) calls the messages in women's magazines so mixed as to be schizophrenic and bewildering. In media, bits of feminist ideology are patched onto patriarchal ideals, making it appear as if patriarchy is evolving into something less sexist, when media are, in fact, reinforcing dominant patriarchal ideals (Caputi, 1987; Vavrus, 2002).

\section{Feminist Media Studies of Masculinity and Violence}

Mass media play an important role in producing hegemonic masculinity (Hanke, 1998). Cuklanz finds that prime time portrayals of rape help "to construct and define a version of hegemonic masculinity in the face of feminist challenges" (2000, p. 4). Cuklanz's description of rape victim representations on television echoes the magazine representations of domestic abuse victims discussed here in the section on findings:

Victims in most cases remain mute, passive, and vulnerable, the objects of pity and aid.... They do little to address their own problems and have few female friends or relatives who can help them. They often blame themselves for their own rapes and rely on professionals for information about counseling and crisis intervention. There are almost no prime time episodes in which women work together to help a friend through the trauma of rape and post-rape efforts to regain a sense of confidence, security, and freedom. (2000, p. 156)

Prushank (2007) finds that the hegemonic male presented in teen magazines might be thoughtful and loving but is

equally as likely to be cruel and freely express anger and rage by dominating females, at times even physically. While these magazines present various constructions of masculinity the ultimate message to teen girls about boys is that she should desire them while she fears them, engage them while she protects herself from them, and be close to them while she waits for them to abandon her. (pp. 173-175) 
Such narratives of boys and men contribute to constructing traditional, violence-linked ideas of masculinity (Consalvo, 2003; Katz, 1999;

Kimmel, 2011).

Prushank finds the patriarchal characteristics of masculinity so naturalized in media "that men find the domination and exploitation of women and other men to be not only expected, but actually demanded" (Prushank, 2007, p. 161). Martin's landmark work with battered women demonstrates that male violence against women is a direct result of inequities in social and cultural power between women and men:

Wife beating ...is a complex problem that involves much more than the act itself or the personal interaction between a husband and his wife. It has its roots in historical attitudes towards women, the institution of marriage, the economy, the intricacies of criminal and civil law, and the delivery system of social service agencies. (Martin, 1976, p. xiv)

The legal and social practice of blaming the victim for rape (and, by extension, for the domestic violence visited upon her) reveals the workings of patriarchy, argues Cuklanz: "the idea of an individual being responsible for or causing someone else's violent attack on her=him is incomprehensible in any context other than traditional patriarchal conceptions of rape" (Cuklanz, 2000, p. 10). Analysis of mainstream newspaper articles finds that domestic violence victims are blamed for their own deaths (Consalvo, 1998; Meyers, 1994). Magazine and newspaper rhetoric often obscures the batterer's responsibility and settles blame and cause upon the battered victim (Lamb, 1991). In her investigation of press coverage of sex crimes, Helen Benedict (1992) finds that the press covers rape "with bias and, sometimes, even cruelty" (p. 3) and suggests that change has been slow in methods of covering sex crimes possibly because rape is commonly covered by male reporters whose work is edited by other men. Bullock (2007) finds domestic violence in newspapers to be obscured in general, and its roots in "socially accepted, gender-based power imbalances" obscured specifically: "Ignoring men's violence against women is perhaps media's most fundamental way of reinforcing the patriarchal status quo" (p. 51). Projansky (2001) argues that media rape narratives have operated historically to 
structure women's relationship to love, family, and the law ...; to produce masculine spectatorial pleasure predicated on illicit (violent) sexuality and culturally sanctioned racism.... Rape narratives help organize, understand, and even arguably produce the social world; they help structure social understandings of complex phenomena such as gender, race, class, and nation. (p. 3)

In her study of how rape is portrayed in popular magazines, Susan Caringella-MacDonald (1998) characterizes media portrayals of rape as "hegemonic, buttressing the patriarchy that undergirds structural inequality and sexism and the rampant rape that these engender" ( $p$. 63).

Media coverage of exceptional cases of violence, such as stories about sports or music celebrities who beat their wives, shifts responsibility away from social systems and patriarchal attitudes that foster and support the larger problem of widespread male violence and, instead, demonizes a few, troubled men (Stanko, 1985; Willis, 1994). This type of representation also works to obscure the social and cultural structures that allow violence against women to occur (Stanko, 1985). Meyers (1997) argues that by "reflecting this cultural blindness, the news reinforces it-and thereby contributes to the perpetuation of violence against women" ( $p$. ix). Media narratives that repeatedly reiterate certain social scripts of who is the victim and who is the criminal work to perpetuate "the most harmful ideologies of race and gender" (Stabile, 2006, p. 175).

In her study of how men's magazines and political magazines portray domestic violence, Nancy Berns calls this "degendering the problem and gendering the blame" (2001, p. 262); "engendering blame" is a term Meyers (1997) employs in her earlier analysis of news coverage of domestic violence. The problem is degendered in this way: the violence of men is repositioned as violence in general, with the condition of gender excised. The responsibility is gendered in this way: female victims are blamed for being victims. This allows the roles of gender and power to be overlooked in considering the social problem of domestic violence, repositions the issue as a woman's private problem (Berns, 1999) and "plays a central role in resisting 
any attempts to situate social problems within a patriarchal framework" (Berns, 2001, pp. 265-266).

Domestic violence has become a social problem about the victims. Most media stories focus on the victim. The victim is celebrated for having the courage to leave the abusive relationship or, conversely, blamed for staying and letting the abuse continue. He or she is accused of provoking the abuse and held responsible for ending the abuse. The victim is told to take back his or her power and refuse to tolerate the abuse anymore. Though not every story covers all these themes, together they represent the dominant portrayal of domestic violence in popular media. This focus may help build support for programs that help victims of domestic violence. However, it does little to develop public understanding of the social context of violence and may impede social change that could prevent violence. Along the way, the violence and the abuser have gotten lost. (Berns, 2004, pp. 2-3, italics in original)

Magazines provide potent instruction in social interaction. Adolescent boys learn how to treat young women from the imagery and information in men's magazines and pornography (Burton, Kitzinger, Kelly, \& Regan, 1998; Measor, Tiffin, \& Fry, 1996). Diana E. $\mathrm{H}$. Russell (1993) finds that male exposure to pornographic media images can lead to committing acts of violence against women. Russell (1990) argues that treating rape as an act of an individual deviant is inaccurate, and that violence against women actually conforms to ideals of masculinity.

Representations of domestic violence in mass media work to form social beliefs about the seriousness of the issue, who and what is to blame, and what resources might be applied to addressing the problem. Mass media representations are important because they "inculcate individuals with the values, beliefs, and codes of behavior that will integrate them into the institutional structure of the larger society" (Herman \& Chomsky, 1988, p. 1). Domestic violence kills women, presents significant health risks to children, sows the seeds of future violent offenders, and strains the nation's health care resources. Yet, as this study demonstrates, the social and cultural forces that support and allow violence against women remain utterly unaddressed in popular magazine discourse on domestic violence. In men's 
magazines, domestic violence is mentioned only in passing or humorously or as if statistics and women are exaggerating the problem. And women's magazines, as previous literature indicates is likely, work to reinforce the idea that when it comes to domestic violence, the victim is responsible for the violence and its prevention.

\section{Theory and Method}

Building on the extensive domestic violence research already conducted on newspapers and television (Benedict, 1992; Bullock, 2007; Consalvo, 1998; Cuklanz, 2000; Lamb, 1991; Meyers, 1994; Stabile, 2006; Stanko, 1985), I turn to extending the more limited research of domestic violence in popular magazines (Berns, 2001; Caringella-MacDonald, 1998). Popular magazines are a site of target audiences often segmented by gender, class, and race. In this study, examine magazines in terms of gendered readership. In future research, class and race would be additional dimensions to explore, as domestic violence is prevalent among all socioeconomic classes and as celebrities of color may be represented in an unbalanced manner regarding domestic violence. Discourse from more magazine titles also deserves scholarly attention. Examination of the differences between how men and women use and respond to magazines would also be useful in estimating the importance of the difference in messages between men's and women's publications.

Magazines, rather than newspapers, were chosen as texts because this study examines how the issue is discussed and characterized, not how it is reported. I selected men's and women's magazines using two criteria. One was high circulation; magazines reaching large audiences would logically affect larger numbers of readers. The other was electronic archive availability. Searching through 10 years of magazines by hand was not possible, so circulation lists (Advertising Age, 2008; Association of Magazine Media, 2008; BurrellesLuce, 2008) were culled by which magazines were available in full text electronic versions from online databases. I did not filter magazines by type; the top five magazines available electronically were used, regardless of the subject matter. Therefore the women's magazines include a fitness title, and the men's magazines include a sports magazine and Popular Science. The 
resulting five women's magazines were Cosmopolitan, Marie Claire, Redbook, O: The Oprah Magazine, and Shape. The five men's magazines were Sports Illustrated, Rolling Stone, Esquire, Men's Health, and Popular Science. A sample of only lifestyle magazines would make a good follow-up companion study to this one. I examined magazines over 10 years beginning in 1998 because this is about the point where Berns's work leaves off. Search phrases were "domestic abuse," "domestic violence," "relationship violence," and "anger management," the latter added to catch articles that might advise abusers on how to stop abusing. Each article retrieved was read, and irrelevant articles were discarded. In the final tally of articles mentioning or focusing on domestic violence between 1998 and 2008, five leading men's magazines yielded 77 articles and five leading women's magazines yielded 101 articles.

What constitutes an "article" requires explanation. Women's magazine articles in this study are, almost always, about the subject of domestic violence and are often 700 or more words. In contrast, men's magazine articles tend to briefly mention domestic violence in a line or two, either as a short news item (31 of these) or as a passing mention within the context of a story that is not about domestic violence (25 of these). I include these brief mentions because they characterize domestic violence discourse in men's magazines. Of the 77 articles mentioning domestic violence in men's magazines, 56 fall into this "brief mention" category. Two examples:

Martin's production may decrease now that Artest is back in the lineup-he was serving a seven-game suspension for pleading no contest last summer to a domestic violence charge-but if he continues his all-around play, the league's most unheralded player will soon become a household name. (Mannix, 2007)

Suspended by the NBA for the first seven games of next season, Kings forward Ron Artest and Warriors forward Stephen Jackson, for their recent off-the-court legal problems. In May, Artest pleaded no contest to a domestic violence charge stemming from an argument with his wife, Kimsha. (Mannix, 2007) 
There are two lengthy articles on domestic violence in men's magazines: one arguing that anger therapy is ineffective for abusers, and another package of short pieces on rage.

This study is a narrative analysis, combining critical cultural studies with feminist theory to consider the intersections of gender, race, and class, and the expressions of hegemonic forces (Meyers, 2004). Narrative analysis focuses not on the story but on how the story is told-and, in this case, also on how the story is not told. It is critical to read silences and absences in gendered discourse because the implications and assumptions within them may be powerful statements of hegemonic forces. In taking note of what is absent, I follow George Gerbner (1972) and Gaye Tuchman (1978) in labeling omission from media as "annihilation" of a group or event. Cuklanz notes that feminist and feminine voices are often absent from the very discussions that most affect them:

The silencing of groups and individuals who wish to speak against established practices, beliefs, policies, and definitions is central to the maintenance of existing power relations ...discovering and exposing the means by which people are silenced are the first steps in the effort to oppose and resist them. (2000, p. 2)

\section{Findings: Themes and Absences}

Analysis reveals that domestic violence coverage in women's and men's magazines does appear to split significantly along gender lines in frequency, tone, and themes. Women's magazines commit significant space to lengthy articles focused on domestic violence and return to the subject frequently-in some cases, in each issue. Men's magazines take up the topic less often and only rarely devote an article to the topic specifically. Women's magazine articles on domestic violence are uniformly serious; men's magazine articles on domestic violence are often humorous and playful. Women's magazines hold women responsible for having men in their lives who become violent; men's magazines generally do not hold men responsible for committing violence. I now turn to a discussion of four themes found in the narratives.

Women's Studies in Communication, Vol. 34, No. 2 (2011): pg. 139-160. DOI. This article is (C) Taylor \& Francis (Routledge) and permission has been granted for this version to appear in e-Publications@Marquette. Taylor \& Francis (Routledge) does not grant permission for this article to be further copied/distributed or hosted elsewhere without the express permission from Taylor \& Francis (Routledge). 


\section{Women Are Responsible and Men Can't Help Themselves}

The narratives of women's magazines promote the idea that women are responsible for every aspect of domestic violence: identifying potentially violent men, successfully avoiding them, helping others leave violent relationships, understanding the workings of the legal system, knowing where shelters are located, carrying hotline numbers in their handbags, being prepared to immediately leave their homes and jobs should violence occur, and working as activists to prevent domestic abuse (Booth, 2007; Davis, 2000, 2007; DeLong, 2005; France, 2006; Torneo, 2005a). Headlines steer readers toward assuming responsibility for predicting future criminal behavior in persons who have as yet committed no crime: "The Type of Guy Who's Prone to Aggression" (Booth, 2007) and "How to Spot a Guy Who Is Apt to Get Unhinged" (Booth, 2007). Articles warn of "triggers" that spark male violence, such as fatherhood, work stress, economic stress, jealousy, and breaking up (Booth, 2007; DeLong, 2005). In these ways, women's magazines hold women responsible for managing male stress and for predicting and avoiding crime. Responsibility for predicting and then avoiding crime is placed onto the victims. Articles that offer tips and guidance for resisting attackers, such as "How to Talk Your Way Out of a Date Rape" (Davis, 2000), imply that victims who fall prey to attack are at fault for not employing proper techniques to prevent their victimization.

Women's magazine narratives place women in guardianship of other women, instructing readers to intervene with friends who are being abused. Marie Claire, Cosmopolitan, and O: The Oprah Magazine present information for readers to pass along to abused friends so consistently that it serves as instruction for readers, should they be abused. Cosmopolitan offers four tips for talking to abused friends: voice your suspicions, give her facts and statistics, stay in her life even if she stays with the violent man, and give her phone numbers of hotlines and shelters (Booth, 2007). In "How to Help a Friend," O: The Oprah Magazine (2006) suggests keeping spare car keys and cash for her in case she needs to flee. In "You May Think That Domestic Violence Has Nothing to Do With You," Redbook urges readers to reach out to friends in abusive relationships to convince them to leave before 
it is too late (Welch, 2007). These narratives promote the idea that the appropriate social response to domestic violence is for the woman to abandon her life and flee.

The narratives of men's magazines promote the idea that men are not responsible for their domestic violence and that they cannot help themselves for a variety of reasons, including male biology, difficult childhoods, sports careers, and military service. An Esquire article-discussing how stressful military service may lead to domestic violence-frames violence as being triggered by a woman, and frames the violent man in near-laudatory words:

"This is what's gonna happen," says John P. Wilson, the nation's foremost expert on PTSD among soldiers and a frequent expert witness in criminal trials. "With these guys coming home, the rates of PTSD will get real high. You'll have this hypervigilant, hyperaroused guy, and then you're gonna get a trigger. In domestic-violence cases, it's gonna be an argument, and the guy is gonna snap." (Rosenwald, 2006)

This narrative theme is sometimes communicated with humor, which naturalizes aggression as understandable and human: "Men are men: Much is beyond fixing. We're gonna scratch our nuts, fart freely, drive fast-and many of us, helplessly bobbing in tides of biology and culture, habitually turn to aggression to cope with our anger and frustration" (Raab, 2000).

In an Esquire special report on men and rage, writer Scott Raab reports, "This year, nearly two million men will boil over and smack her" (Raab, 2000). The phrase boil over implies a matter of only a few degrees of difference between nonviolent behavior and beating a woman, suggesting that men are exercising admirable control when they are not hitting a woman. The word smack makes physical abuse sound cartoonish and distances it from causing serious harm or death. In this article, Raab takes an approach that seems to position the reader as being more reasonable than abusive men but might also serve to align the reader as being not so very different from men whose violence tips over the edge to assault: 
NOT THE PUBLISHED VERSION; this is the author's final, peer-reviewed manuscript. The published version may be accessed by following the link in the citation at the bottom of the page.

Have you ever hit a woman? Gosh, no. What sort of nasty prick do you think I take you for? Me neither. But have you ever picked up a chair and smashed it against the floor so hard it broke? Yelled at her for not having dinner ready? Thrown a plate of food against the wall? Punched a hole in the door? Shouted threats at the top of your lungs? Called her names that you'd kill anyone else for calling her? And blamed her for the whole goddamn mess? Yeah-me, too. Not that this story is about me. Or you. This story is about those other guys, the men who batter women, who go too far. This story is about fixing those menthe abusers. Not us. (Raab, 2000)

Unreasonable and aggressive acts against women are often positioned in men's magazines as something other men would understand, forgive, and possibly even do themselves. In an article about the night he attacked his wife, Pamela Anderson, because he could not locate a particular frying pan, Tommy Lee told Rolling Stone:

Pamela, in my mind, was disrespecting my feelings [about the seriousness of having lost a frying pan].... And then Pamela said the words that you should never say to anyone who's losing their temper, the words that only pour gasoline on the blaze: "Calm down. You're scaring me." (Strauss, 2001)

Lee characterizes as reasonable his intense focus on finding a frying pan and as disrespectful his wife's fear as he threw pots and pans and yelled. In this article, Lee's characterizations remain essentially unchallenged. His illogical thinking is presented as understandable, and the confusion and fear of his wife is blamed as the trigger for the escalation of violence.

In Sports Illustrated, domestic violence by sports stars is sometimes excused, as in a profile of a sports celebrity with a history of hitting his wife: "Should a man still be held accountable for an incident that, though troubling, seems isolated? Not if the incident is truly isolated" (Greenfeld, 2004). In an article on Roy Tarpley, domestic abuse is equated to a speeding ticket and then excused because of his athletic performance; in an article on Riddick Bowe, domestic abuse is excused because of Bowe's winning personality.

And it's true, there is a misdemeanor quality to his rap sheet, speeding tickets, disappearances from the team, some domestic

Women's Studies in Communication, Vol. 34, No. 2 (2011): pg. 139-160. DOI. This article is (C) Taylor \& Francis (Routledge) and permission has been granted for this version to appear in e-Publications@Marquette. Taylor \& Francis (Routledge) does not grant permission for this article to be further copied/distributed or hosted elsewhere without the express permission from Taylor \& Francis (Routledge). 
violence. Worst thing he did? Put an iron to his girlfriend's stomach last year. But you older guys know what Tarp gave up. You remember him coming into the NBA in 1986 as a kind of 7foot point guard. He could run the wood, do all the little things, and still swat Hakeem. (Hoffer, McCallum, \& O’Brien, 1998, p. 21)

Bowe's run-ins with the police over domestic abuse calls (once in the week before he went to jail) make it hard to characterize him as entirely happy-go-lucky. But at the time of his ascension, his goofy good nature was almost a national treasure. His wit was exaggerated in the press, but his playfulness was, if anything, underreported. (Hoffer, 2003)

In men's magazines, violent behavior in relationships is sometimes compared to minor infractions on the playing field: "[Redskins Dan Wilkinson pleads] no contest to a domestic violence charge after being accused of striking his pregnant girlfriend. He had also feuded with Bengals coaches about his playing weight" (King, 1998), and this account of why a female fan might dislike Ball State forward Bonzi Wells:

It could have been the postgame slap Wells gave an opposing player after a game at Central Michigan last season. Or maybe it was the two ejections for jawing with the referees Wells earned the year before that. A broadcast report of domestic violence two years ago might have been on her mind (though charges were never filed). (Anderson, 1998)

Equating physical assault off the field with competitive sports behavior is dismissive of the seriousness of domestic violence.

\section{Domestic Violence Is Terrifying to Women and Funny to Men}

Women's magazine articles about domestic violence often employ fear-inducing language and take on a dramatic, ominous tone. Headlines are typically lurid and fear-mongering, such as Cosmopolitan's "Murdered by the Men They Love," "Murdered by the Man of Her Dreams," "The Most Dangerous Breed of Men," and "When Love Turns Deadly" (DeLong, 2005); "Scary New Ways Stalkers Come

Women's Studies in Communication, Vol. 34, No. 2 (2011): pg. 139-160. DOI. This article is (C) Taylor \& Francis (Routledge) and permission has been granted for this version to appear in e-Publications@Marquette. Taylor \& Francis (Routledge) does not grant permission for this article to be further copied/distributed or hosted elsewhere without the express permission from Taylor \& Francis (Routledge). 
After Women" (Fairstein, 2007); "Why the End of a Relationship Can Be a Violent Beginning" (Booth, 2007); and "Fear Can Be Your Friend" (Fairstein, 2008). "One in Three Women Will Be Abused in Her Lifetime" is a detailed recounting of the violent relationships and eventual murders of five young women ("One in Three Women," 2003). An O: The Oprah Magazine article tells the story of two sisters, each in an abusive relationship; one dies, and one lives to write the story (Latus \& Brodey, 2005). Alarming language helps create a sense of moral panic, yet in the case of domestic violence the moral panic does not implicate violent men as much as the women who are attached to them.

In contrast, men's magazines often employ playful, lighthearted, and even humorous language, as in these Men's Health headlines: "Who's Throwing Stuff and Who's Getting Hit" (Vigneri, 2000), "Shedunnit! Six Signs Your Angel of Death May Have Worn High Heels" (Marion, 2000), and "Girls Gone Postal: She's fire and brimstone. You're deer in the headlights. Eleven ways to calm her before things get really sticky" (Stains, 2003).

Esquire gives a mock award to the wife of Maryland governor Robert Ehrlich for saying, "If I had an opportunity to shoot Britney Spears, I think I would," and then adds, "Us, too, but we'd bang her first. Oh, like you weren't thinking it" (Auslander, 2004, p. 70).

In a Sports Illustrated article about basketball player Allen Iverson: "Who throws his wife onto the lawn, naked, in the middle of the night, in the manner of an aggrieved Fred Flintstone putting out the cat?" At the end of the story, the writer admits that Iverson's domestic violence case "is nothing to wallow in, even as we're doing so right here. Domestic violence crimes involving guns are all too common in America. You needn't be M. Night Shyamalan to know how these stories often end. I see dead people" (Rushin, 2002, p. 17). Despite his demurring in the final paragraph, Rushin's Flintstone reference positions domestic violence as a source of entertainment for men.

When men's magazines discuss male victims of domestic violence, the tone is also humorous: 
Angry men are good on technical merit-they pull guns and get the job done. But give the chicks points for artistic impression: boots (Tawny Kitaen), matches (Lisa Lopes), a steak knife (Lorena Bobbitt) - the ladies will summon practically anything as a weapon. (Stains, 2003, p. 106)

In a Popular Science story titled "Every Step You Take ... Every Move You Make ...My GPS Unit Will Be Watching You," male readers are promised that "stalking today is not only easier, it's virtual-which dramatically lessens the chance of getting caught in the act" and are taught ways to view her whereabouts on his cell phone using a global positioning system (GPS) and hide a camera in her bedroom alarm clock (Rosenwald \& Allen, 2004). Under the guise of sarcastic humor, Esquire claims rage as a male right:

Fuck you. That's right-fuck you. I've got your angermanagement technique right here, dangling. Check it out-and while you're down there, kiss my crack .... I do a lot of screaming, mostly profane. First off, I live and drive in north Jersey. Number two, my wife's a woman .... I gotta tell ya, rage makes me feel so alive .... I sleep angry. Without rage, I'm dead. (Raab, 2007, p. 82)

There is humor in this article, but there are also claims that women are a primary reason for male rage and that violent and aggressive male rage is perhaps a survival mechanism (and therefore essential) for men.

\section{Statistics Unjustly Blame Men for Domestic Violence}

Men's magazines argue that statistics about male violence are misleading: "The media and the Ad Council may have helped create the myth of the malevolent male, but this is how the hitters really stack up" (Vigneri, 2000, p. 150). Men's Health readers are directed to a Web site "to see how the U.S. Department of Justice and other law enforcement organizations are oriented toward seeing women as victims and men as perpetrators" (Vigneri, 2000, p. 150). Statistics about violent male behavior are reported but then criticized on the grounds that is it hard to believe that as many as 9.3 percent of the men in America would actually destroy property or hit someone (Men's 
Health, 2002). Men's Health claims there is "public service hysteria about spousal abuse" and that it maligns men (Zoellner, 2000).

Humor and sarcasm are used heavily in men's magazine representations of male victims of domestic violence, as evinced in headlines such as "Femmes Fatales!" (Zoellner, 2000) and "Mad About You" (Men's Health, 2002). With gravity and no sense of irony, the magazine warns readers that an angry woman's typical and most devastating target is "your car" (Men's Health, 2002). In "Girls Gone Postal," Laurence Roy Stains offers advice for calming an angry woman: "next time your little honeybee turns mad as a hornet, here's how to stop the buzzing" (Stains, 2003, p. 106). The article reports that women are violent because they can "get away with it" (Stains, 2003, p. 106), perhaps implying that violent women are not considered serious threats to men and are treated less harshly by the legal system.

In women's magazines, female victims who stay with a violent man are characterized as having low self-esteem. In men's magazines, male victims of domestic violence are characterized as staying because they don't take the problem seriously (Stains, 2003). Men's Health advises male victims of domestic violence to stop picking up strangers in bars and to avoid fighting in the kitchen where there are knives, the "favorite weapon" of women (Stains, 2003). Women's magazines advise female victims of domestic violence to leave their jobs, take their children out of school, abandon their homes, and run. Redbook cautions, "If you're in a dangerous situation and need to flee with nothing but the clothes you are wearing, says Rose Pulliam, president of the National Domestic Violence Hotline, don't hesitate-do it" (Davis, 2007). Cosmopolitan applauds an abused woman who relocated her life (and had enough resources to buy a decoy plane ticket):

Moving away to a different city, even temporarily, may be the best solution. "He can't hurt you if he can't find you," says Schwartz. Kelly, who was beaten by her lawyer boyfriend, took that step, starting over in a nearby town. "I knew he would be monitoring my credit-card statements, so I bought a plane ticket to another city to throw him off my trail," she says.

Women's Studies in Communication, Vol. 34, No. 2 (2011): pg. 139-160. DOI. This article is (C) Taylor \& Francis (Routledge) and permission has been granted for this version to appear in e-Publications@Marquette. Taylor \& Francis (Routledge) does not grant permission for this article to be further copied/distributed or hosted elsewhere without the express permission from Taylor \& Francis (Routledge). 
"Luckily, he never found me. I only wish I'd done it sooner." (Booth, 2007, p. 146)

As previously noted, in women's magazines, women are given responsibility for both the violence that men do and the violence that women do. Although the majority of domestic violence perpetrators are men (Berk, Berk, Loseke, \& Rauma, 1983; Brush, 1990; Dobash \& Dobash, 1979; Schwartz, 1987), more than $10 \%$ of the articles in women's magazines in this study advised women on how to not become violent in relationships. Cosmopolitan instructs readers to "know your tantrum triggers" such as "stress, lack of sleep, substance abuse, low blood sugar, and sickness" and then "learn tricks that help you simmer down" (Torneo, 2005a, p. 183). Redbook offers a sevenday program for women to manage anger and reduce stress, counseling readers to conduct a "yelling reality check," "recognize the warning signs," "learn to take a breather," and to try five other "quirky anger tamers that work" (Bannan, 2003, p. 118). Redbook advises women to de-escalate their own slapping and hitting and instead try to reason with their boyfriends (Torneo, 2005b). Similar advice on handling anger in relationships is not offered to men in magazines, although there are one or two mentions of how men might deal with anger in the workplace.

\section{What Help Looks Like: Shelters and Avoidance}

More than half the articles in women's magazines encourage readers to march, advocate, or raise funds to build shelters and fund education for women that is aimed at convincing victims to leave abusers. Domestic violence "activism" as supported by women's magazines includes wearing symbolic bracelets, ribbons, and jewelry, such as Marie Claire's \$29.95 charm necklace, which comes with three cards printed with a domestic abuse hotline number to leave "in your gym's locker room or a public restroom" (2006). Marie Claire identifies domestic violence as its "most important mission ever" (Savacool, 2005) and carries out this mission by printing stories of abuse, asking women to let victims know "they are not alone" (Marie Claire, 2006), and awarding prizes to celebrities who raise funds to build shelters or staff hotlines. Shape asks readers to nominate domestic violence victims for recognition as survivors (Gayagoy, 2005), and Marie Claire 
awards "women of the world" prizes to celebrity and international efforts to help women, often in the area of domestic violence prevention and shelters (McKelvey, 2004). A Redbook article, titled "Yes, You Can Stop Violence Against Women" (Davis, 2007), offers an unattainable goal in its headline and holds women responsible for changing a social condition without involving men in the problem solving or action taking. The article commends state and federal governments for "protecting women" by paying unemployment to victims who must relocate, by making it illegal (in some states) to fire a victim because she misses work to testify in court, and by no longer removing children from their mother's care because she is abused. Although these measures seem more like the suspension of unfair persecutions of crime victims rather than enlightened policies, the tone of the article is celebratory.

Some men's magazines include critical narratives about therapy for abusers (research about how ineffective these therapies tend to be is referenced earlier in this article). An Esquire article exploring courtordered therapy for domestic abusers denounces what it labels the "profeminist" model of anger management utilized in the therapy (Raab, 2000).

\section{Discussion}

Women are guilty of choosing the wrong men; men are not guilty of hitting women. Women are held responsible for knowing what men might do in the future and for being present when men become violent. Male abusers are not forced out of violent relationships; female victims are instructed to leave. There is no other crime, save rape (and the parallels are obvious), for which the victim is held responsible. She must absorb all the change and debt and difficulty. She must dismantle her life and the lives of her children; she must disrupt her community ties, her job, her educational goals and opportunities, and create her own victim protection program because the police cannot protect her and because women who leave are often killed for doing so.

By representing domestic violence as occurring "naturally" among men and as being something men cannot prevent, by 
mentioning the issue only in passing rather than in entire articles devoted to the topic, by offering explanations and excuses for domestic violence, by treating it as an isolated incident rather than a systemic problem, and by employing humorous and playful language, men's magazines are dismissive toward domestic violence.

As this study shows, the most frequently occurring narrative in women's magazines about domestic violence is how women can work to "prevent" domestic violence-yet these efforts do not prevent any violence but simply relocate women into shelters or away from abusers. Without denigrating the importance of family shelters and the hardworking and heartfelt efforts of domestic violence advocates and volunteers, these are not preventive efforts. These are efforts to aid victims: important and compassionate aid, but not preventive or effective in reducing domestic violence. Framing rescue efforts as "prevention" is disingenuous. The victims have gone into hiding, but no crime has been prevented, just postponed. Should the victims become accessible again, the battering would resume. Labeling relocation as "prevention" assists in overlooking male responsibility. Prevention efforts are typically aimed at causes of a problem, but not in the case of domestic violence. Discourse aimed at preventing domestic violence would need to address not only how individual men handle rage but the far-ranging cultural attitudes that reveal the patriarchal underpinnings of society. In addition, focusing "prevention" efforts on women extends what Berns aptly named the process of "degendering the problem and gendering the blame" (2001). For example, while Liz Claiborne works with Redbook to teach women how to leave violent men (Davis, 2007), no men's deodorant or sports gear companies work with men's magazines to educate men about handling their rage.

The character of these magazine narratives contributes to a set of cultural and social expectations that ultimately allows men to strike women. Of course, all men are not violent, nor do all men sanction violence. And of course, some batterers do go to jail and are punished. However, media hold women responsible for most aspects of the domestic violence issue-education, funding, volunteering, prevention-and represent men as hapless victims, afloat in a sea of hormones and cultural flotsam. Women are represented as a 
contradictory blend of victim and responsible party, and men are represented as inept at managing their emotional lives and unable to contain their actions to fit within the bounds of civility.

It is almost as if these two bodies of texts come from different worlds where domestic violence is two very different things. Reading men's magazines, a reader would never realize the epidemic proportions of family violence, the damage it does to children, the money it costs the nation, and the likelihood it will escalate into murder.

\section{Absences in the Narratives}

The absences of representation speak loudly. No narratives offer resistance to the popular canon that women must leave, women must change, women must be vigilant, women must cure and treat and prevent. No narratives give men an active role in reducing domestic violence. No narratives include men who take responsibility for having been or for being violent. There is an absence of representations of women who act swiftly to protect themselves and their children, and of caring men who protect their families. Men who care about this issue are invisible in the media, making it seem as if they do not exist in reality. There are no narratives about how men and women might come to terms with being raised in a culture where violence is venerated as a male-sanctioned activity and as a sign of male dominance and prowess. And there are no narratives addressing patriarchy's role in domestic violence or exploring the cultural and social conditions and attitudes that allow domestic violence to exist.

There are no narratives of success stories of once-violent men who become loving, nonviolent partners. There are no narratives of healed relationships, of women leaving fear behind and learning to feel secure, of men who accept responsibility for their actions and who learn new ways to relate to women and to resolve conflict. Conflating victim support (shelters, hotlines, and education) with true prevention and treatment obscures what truly causes violence-and thus how violence might actually be effectively addressed. Men's magazines offer no advice to men on how to deal with their own anger or violence 
or on how to help friends who are abusive. Men's magazines do not include stories of the fear and injuries women sustain.

These absences in representation serve to symbolically annihilate the possibility that men and women might work together with common goals to reduce domestic violence. Such absences shroud male violence against women in mystery and futility, as though it is an unsolvable problem that might never be improved-and by treating it as such, it is rendered to be so.

The causes of domestic violence are complex and inextricably bound into the fabric of social and cultural expectations of the genders. Some popular media is not suited or practiced in unraveling complex and nuanced social issues; on the other hand, there is a long-standing journalistic tradition of muckraking and "outing" social inequities and wrongs. Until men put peer pressure on one another about the unacceptability of domestic violence (and the discourse of men's magazines is one form of such pressure), and until women stop taking and accepting the blame from men (and the discourse of women's magazines is one site of this), it is likely that the blame for domestic violence will remain where it is currently placed. When the victim, rather than the criminal, is held responsible, the crime is likely to never go away.

\section{Conclusion}

Domestic violence is a "product of gender inequality and the lesser status of women compared to men," writes Rachel Jewkes (2002, p. 253). And yet, in 10 years' worth of popular men's and women's magazines, this perspective remains largely unaddressed and unrepresented. The wrong question is asked-"Why does she stay?"instead of "Why does he hit?" Well-meaning media narratives that attempt to directly address domestic violence may contribute to concealing its causes and ultimate preventions.

If women's media contain few to no messages of competent, resourceful women wielding personal agency when dealing with domestic violence, and men's media contain few to no messages of rational men who take responsibility for their violence (or manage 
themselves with enough maturity to never strike another person at all), then women and men may find it difficult to identify the actual problem, situate it within appropriate cultural and social contexts, and work to make domestic peace.

\section{References}

Advertising Age (2008). Magazine circulation rankings index [Data file]. Retrieved from http://adage.com/datacenter/article?article_id=106355

Anderson, K. (1998, January 12). Rebel uprising. Sports Illustrated, 88(1), 75-76.

Association of Magazine Media (2008). Consumer marketing trends: Facts and figures [Data file]. Retrieved from http://www.magazine.org/consumer_marketing/circ_trends/index.asp $\mathrm{X}$

Auslander, S. (2004, February). Dubious achievements 2003. Esquire, 141(2), 70. Bannan, K. J. (2003, June). "I need a calmer life-now!" Redbook, 200(6), 118. Basile, K. C. (2002). Prevalence of wife rape and other intimate partner sexual coercion in a nationally representative sample of women. Violence and Victims, 17, 511-524.

Benedict, H. (1992). Virgin or vamp: How the press covers sex crimes. New York, NY: Oxford University Press.

Berk, R. A., Berk, S. F., Loseke, D. R., \& Rauma, D. (1983). Mutual combat and other family violence myths. In D. Finkelhor, R. Gelles, G. Hotaling, \& M. Straus (Eds.), The dark side of families: Current family violence research (pp. 197-212). Beverly Hills, CA: Sage.

Berns, N. (1999). My problem and how I solved it: Domestic violence in women's magazines. Sociological Quarterly, 40(1), 85-108.

Berns, N. (2001). Degendering the problem and gendering the blame: Political discourse on women's violence. Gender and Society, 15(2), 262-281.

Berns, N. (2004). Framing the victim: Domestic violence media and social problems. Hawthorne, NY: Aldine de Gruyter.

Booth, S. (2007, August). The most dangerous time in a relationship. Cosmopolitan, 243(2), 146.

Brush, L. S. (1990). Violent acts and injurious outcomes in married couples: Methodological issues in the national survey of families and households. Gender and Society, 4, 56-67.

Bullock, C. F. (2007). Framing domestic violence fatalities: Coverage by Utah newspapers. Women's Studies in Communication, 30(1), 34-63.

BurrellesLuce. (2008). Top newspapers and consumer magazines [Data file]. Retrieved from http://www.burrellesluce.com/top100/2008_Top_100List.pdf

Women's Studies in Communication, Vol. 34, No. 2 (2011): pg. 139-160. DOI. This article is (C) Taylor \& Francis (Routledge) and permission has been granted for this version to appear in e-Publications@Marquette. Taylor \& Francis (Routledge) does not grant permission for this article to be further copied/distributed or hosted elsewhere without the express permission from Taylor \& Francis (Routledge). 
NOT THE PUBLISHED VERSION; this is the author's final, peer-reviewed manuscript. The published version may be

accessed by following the link in the citation at the bottom of the page.

Burton, S., Kitzinger, J., Kelly, L., \& Regan, L. (1998). Young people's attitudes towards sexual violence, sex, and relationships: A survey and focus group study. Edinburgh, Scotland: Zero Tolerance Trust.

Caputi, J. (1987). The age of sex crime. Bowling Green, OH: Bowling Green University Popular Press.

Caralis, P. V., \& Musialowski, R. (1997). Women's experiences with domestic violence and their attitudes and expectations regarding medical care of abuse victims. Southern Medical Journal, 90(11), 1075-1080.

Caringella-MacDonald, S. (1998). The relative visibility of rape cases in national popular magazines. Violence Against Women, 4(1), 62-80.

Carpenter, L. M. (1998). From girls into women: Scripts for sexuality and romance in Seventeen magazine, 1974-1994. Journal of Sex Research, 35(2), 158-168.

Consalvo, M. (1997). Cash cow hits the Web: Gender and communications technology. Journal of Communication Inquiry, 21(1), 98-106.

Consalvo, M. (1998). Three shot dead in courthouse: Examining news coverage of domestic violence and mail-order brides. Women's Studies in Communication, 21(2), 188-238.

Consalvo, M. (2003). The monster next door: Media constructions of boys and masculinity. Feminist Media Study, 3(1), 27-45.

Cuklanz, L. (1996). Rape on trial: How the mass media construct legal reform and social change. Philadelphia, PA: University of Pennsylvania Press.

Cuklanz, L. (2000). Rape on prime time: Television, masculinity, and sexual violence. Philadelphia, PA: University of Pennsylvania Press.

Davis, R. (2007, October). Yes, you can stop violence against women. Redbook, 209(4), 220.

Davis, R. G. (2000, December). How to talk your way out of a date rape. Cosmopolitan, 229(6), 258-262.

DeLong, C. (2005, June). When love turns deadly. Cosmopolitan, 238(6), 157-159.

Dobash Emerson, R., \& Dobash, R. P. (1979). Violence against wives: A case against the patriarchy. New York, NY: Free Press.

Duffy, M., \& Gotcher, J. M. (1996). Crucial advice on how to get the guy: The rhetorical vision of power and seduction in the teen magazine YM. Journal of Communication Inquiry, 20, 32-48.

Durham, M. G. (1996). The taming of the shrew: Women's magazines and the regulation of desire. Journal of Communication Inquiry, 20(1), 18-31.

Durham, M. G. (1998). Dilemmas of desire: Representations of adolescent sexuality in two teen magazines. Youth Society, 29(3), 369-389.

Durose, M., Harlow, C. W., Langan, P. A., Motivans, M., Rantala, R. R., Smith, E. L., \& Constantin, E. (2005). Family violence statistics: Including statistics on strangers and acquaintances. Department of Justice NCJ 207846, Bureau of Justice Statistics [Data file]. Retrieved from

Women's Studies in Communication, Vol. 34, No. 2 (2011): pg. 139-160. DOI. This article is (C) Taylor \& Francis (Routledge) and permission has been granted for this version to appear in e-Publications@Marquette. Taylor \& Francis (Routledge) does not grant permission for this article to be further copied/distributed or hosted elsewhere without the express permission from Taylor \& Francis (Routledge). 
NOT THE PUBLISHED VERSION; this is the author's final, peer-reviewed manuscript. The published version may be accessed by following the link in the citation at the bottom of the page.

http://www.icpsr.umich.edu/icpsrweb/NACJD/biblio/series/128/resourc es/36136 ?paging. startRow $=1$ \&publicationYear $=2005$

Evans, D., Rutberg, J., Sather, C., \& Turner, C. (1991). Content analysis 32 of contemporary teen magazines for adolescent females. Youth and Society, 23, 99-120.

Fairstein, L. (2007, January). Scary new ways stalkers come after women. Cosmopolitan, 242(1), 118-121.

Fairstein, L. (2008, March). Fear can be your friend. Cosmopolitan, 244(3), 172.

Ferguson, M. (1983). Forever feminine: Women's magazines and the cult of femininity. Aldershot, England: Gower. France, D. (2006, August). The Laci effect. O: The Oprah Magazine, 7(8), 224-232.

Friedman, L. S., Samet, J. H., Roberts, M. S., Hudlin, M., \& Hans, P. (1992). Inquiry about victimization experiences: A survey of patient preferences and physician practices. Archives of Internal Medicine, $152,1186-1190$.

Garner, A., Sterk, H., \& Adams, S. (1998). Narrative analysis of sexual etiquette in teenage magazines. Journal of Communication, 48(4), 5978.

Gayagoy, G. (2005, June). Honor a domestic-violence survivor. Shape, 24(10), 43.

Gerbner, G. (1972). Violence in television drama: Trends and symbolic functions. In E. A. Rubinstein \& G. A. Comstock (Eds.), Media content and control (pp. 28-187). Washington, DC: U.S. Government Printing Office.

Gondolf, E. (2000). Reassault at 30-months after batterer program intake. International Journal of Offender Therapy and Comparative Criminology, 44, 111-128.

Graham-Bermann, S., \& Seng, J. (2005). Violence exposure and traumatic stress symptoms as additional predictors of health problems in highrisk children. Journal of Pediatrics, 146(3), 349-354.

Greenfeld, K. T. (2004, July 12). A life after wide right. Sports Illustrated, 101(2), 140. 33

Greenfeld, K. T. (2005, February 9). Past Imperfect. Sports Illustrated, 100(5), 20.

Hall, S. (1975). Introduction. In A. C. H. Smith (Ed.), Paper voices: The popular press and social change (pp. 11-24). London, England: Chatto and Windus.

Hall, S. (1988). New ethnicities. In K. Mercer (Ed.), Black film, British cinema (pp. 27-31). London, England: ICA.

Hall, S. (1992). Race, culture, and communications: Looking backward and forward at cultural studies. Rethinking Marxism, 5(1), 10-18.

Women's Studies in Communication, Vol. 34, No. 2 (2011): pg. 139-160. DOI. This article is (C) Taylor \& Francis (Routledge) and permission has been granted for this version to appear in e-Publications@Marquette. Taylor \& Francis (Routledge) does not grant permission for this article to be further copied/distributed or hosted elsewhere without the express permission from Taylor \& Francis (Routledge). 
NOT THE PUBLISHED VERSION; this is the author's final, peer-reviewed manuscript. The published version may be accessed by following the link in the citation at the bottom of the page.

Hanke, R. (1998). The "mock-macho" situation comedy: Hegemonic masculinity and its reiteration. Western Journal of Communication, 62(1), 74-93.

Herman, E., \& Chomsky, N. (1988). Manufacturing consent: The political economy of the mass media. New York, NY: Pantheon Books.

Hermes, J. (1995). Reading women's magazines: An analysis of everyday media use. Cambridge, UK: Polity.

Hoffer, R. (2003, April 14). Blood brothers. Sports Illustrated, 98(15), 68-75.

Hoffer, R., McCallum, J., \& O'Brien, R. (1998, May 25). Days of future passed. Sports Illustrated, 88(21), 21.

Indermaur, D., Atkinson, L., \& Blagg, H. (1998). Working with adolescents to prevent domestic violence: Rural town model. Canberra, Australia: National Anti-Crime Strategy.

Jewkes, R. K. (2002). Intimate partner violence: Causes and prevention. Lancet, 359(9315), 1423-1429.

Katz, J. (1999). Advertising and the construction of violent white masculinity: From Eminem to Clinique for Men. In Dines \& Humez (Eds.), Gender, race, and class in media: A text-reader (pp. 349-358). Thousand Oaks, CA: Sage.

Kernic, M. A., Wolf, M. E., Holt, V. L., McKnight, B., Huebner, C. E., \& Rivara, F. P. (2003). Behavioral problems among children whose mothers are abused by an intimate partner. Child Abuse and 34 Neglect, 27, 12311239.

Kimmel, M. (2011). Manhood in America: A cultural history. New York, NY: Oxford University Press.

King, P. (1998, July 27). Heaven sent. Sports Illustrated, 89(4), 56-60.

Lamb, S. (1991). Acts without agents: An analysis of linguistic avoidance in journal articles on men who batter women. American Journal of Ortliopsychiatry, 61(2), 250-257.

Latus, J., \& Brodey, D. (2005, October). All the wrong men. O: The Oprah Magazine, 6(10), 265-270.

Lawrence, S. (2002). Domestic violence and welfare policy: Research findings that can inform policies on marriage and child well-being, research forum on children, families, and the new federalism. National Center for Children in Poverty, Domestic Violence and Welfare Policy, Mailman School of Public Health. New York, NY: Columbia University.

Mannix, C. (2007, December 3). Points unknown. Sports Illustrated, 107(22), 38.

Marie Claire. (2003, October). One in three women will be abused in her lifetime. Marie Claire, 10(10), 131-135.

Marie Claire. (2006, November). Help stop domestic violence. Marie Claire, $13(11), 48$.

Women's Studies in Communication, Vol. 34, No. 2 (2011): pg. 139-160. DOI. This article is (C) Taylor \& Francis (Routledge) and permission has been granted for this version to appear in e-Publications@Marquette. Taylor \& Francis (Routledge) does not grant permission for this article to be further copied/distributed or hosted elsewhere without the express permission from Taylor \& Francis (Routledge). 
NOT THE PUBLISHED VERSION; this is the author's final, peer-reviewed manuscript. The published version may be

accessed by following the link in the citation at the bottom of the page.

Marion, M. (2000, May). Shedunnit! Six signs your angel of death may have worn high heels. Men's Health, 15(4), 152.

Martin, D. (1976). Battered wives. San Francisco, CA: Glide.

McCauley, J., Yurk, R. A., Jenckes, M. W., \& Ford, D. E. (1998). Inside "Pandora's box": Abused women's experiences with clinicians and health services. Archives of Internal Medicine, 13(8), 549-555.

McCracken, E. (1993). Decoding women's magazines: From Mademoiselle to Ms. New York, NY: St. Martin's Press.

McFarlane, J., Campbell, J. C., Wilt, S., Sachs, C. J., Ulrich, Y., \& Xu, X. (1999). Stalking and intimate partner violence. Homicide Studies, 3(4), 300-316.

McKelvey, T. (2004, December). Women of the world awards. Marie Claire, 11(12), 84-90.

Measor, L., Tiffin, C., \& Fry, K. (1996). Gender and sex education: A study of adolescent responses. Gender and Education, 8(3), 275-288.

Men's Health (2002, May). Mad about you. Men's Health, 17(4), 150.

Merskin, D. (1999). Adolescence, advertising, and the ideology of menstruation. Sex Roles, 40(11-12), 941-957.

Meyers, M. (1994). News of battering. Journal of Communications, 44(2), 4763.

Meyers, M. (1997). News coverage of violence against women: Engendering blame. Thousand Oaks, CA: Sage.

Meyers, M. (2004). Crack mothers in the news: A narrative of paternalistic racism. Journal of Communication Inquiry, 28(194), 194-216.

Miller, T. R., Cohen, M. A., \& Wiersema, B. (1996). Victim costs and consequences: A new look [Data file]. National Institute of Justice Research Report, February 1996. U.S. Department of Justice. Retrieved from http://www.ipsr.umich.edu/NACJD/jij_pubs.html Mravic, M. (2001, January 8). The beat. Sports Illustrated, 94(1), 26. O: The Oprah Magazine (2006, August). How to help a friend. O: The Oprah Magazine, 7(8), 204-208. Peirce, K. (1990). A feminist theoretical perspective on the socialization of teenage girls through Seventeen magazine. Sex Roles, 23(9=10), 491-500.

Peirce, K. (1995). Socialization messages in Teen and Seventeen magazines. In Cynthia M. Lont (Ed.), Women and media: Content, careers, and criticism (pp. 79-86). Belmont, CA: Wadsworth.

Projansky, S. (2001). Watching rape: Film and television in postfeminist culture. New York, NY: New York University Press.

Prushank, D. (2007). Masculinities in teen magazines: The good, the bad, and the ugly. Journal of Men's Studies, 15(2), 160-177.

Puffett, N. K., \& Gavin, C. (2004). Predictors of program outcome and recidivism at the Bronx Misdemeanor Domestic Violence Court. New York, NY: Center for Court Innovation. Retrieved from

Women's Studies in Communication, Vol. 34, No. 2 (2011): pg. 139-160. DOI. This article is (C) Taylor \& Francis (Routledge) and permission has been granted for this version to appear in e-Publications@Marquette. Taylor \& Francis (Routledge) does not grant permission for this article to be further copied/distributed or hosted elsewhere without the express permission from Taylor \& Francis (Routledge). 
http://www.courtinnovation.org/_uploads/documents/predictorsbronxd v.pdf

Raab, S. (2000, September). Men explode. Esquire, 134(3), 244-256.

Raab, S. (2007, April). The endorsement: Rage. Esquire, 147(4). Retrieved from http://www.esquire.com/features/the-endorsement/rage0407

Rakow, L. (2001). Feminist approaches to popular culture: Giving patriarchy its due. In John Storey (Ed.), Cultural theory and popular culture: A reader (pp. 275-291). Athens, GA: University of Georgia Press.

Rodriguez, M. A., Quiroga, S. S., \& Bauer, H. M. (1996). Breaking the silence: Battered women's perspectives on medical care. Archives of Family Medicine, 5(3), 153-158.

Rosenwald, M. (2006, October). The Iraq defense. Esquire, 146(4), 74.

Rosenwald, M., \& Allen, L. (2004). Every step you take ...Every move you make ... My GPS unit will be watching you. Popular Science, 265(5), 88.

Rushin, S. (2002, July 29). Summery judgment. Sports Illustrated, 97(4), 17.

Russell, D. (1990). Rape in marriage. Bloomington, IN: Indiana University Press.

Russell, D. (1993). Against pornography: The evidence of harm. Berkeley, CA: Russell Publications.

Santa Cruz, A. (1995). Fempress: A communication strategy for women. Gender and Development, 3(1), 51-54.

Santa Cruz, A., \& Erazo, V. (1980). Compropolitan: El orden transnacional y su Modelo femenino, Un studio de las revistas femininas en America Latina. Mexico City, Mexico: Editorial Nueva Imagen=Instituto Latinoamericano de Estudios Transnacionales.

Savacool, J. (2005, October). Join Marie Claire in our most important mission ever. Marie Claire, 12(10), 106-113.

Schlenker, J., Caron, S. L., \& Halteman, W. A. (1998). A feminist analysis of Seventeen magazine: Content analysis from 1945 to 1995. Sex Roles, $38,140$.

Schwartz, M. D. (1987). Gender and injury in spousal assault. Sociological Focus, 20, 61-75.

Singer, M. I., Miller, D. B., Guo, S., Slovak, K., \& Frierson, T. (1998). The mental health consequences of children's exposure to violence. Cleveland, OH: Cuyahoga County Community Mental Health Research Institute, Mandel School of Applied Social Sciences, Case Western Reserve University.

Stabile, C. A. (2006). White victims, Black villains: Gender, race, and crime news in U.S. culture. New York, NY: Routledge.

Stains, L. R. (2003, June). Girls gone postal. Men's Health, 18(5), 106.

Stanko, E. (1985). Intimate intrusions. London, England: Routledge Kegan Paul. 
Stark, E., \& Buzawa, E. S. (2009). Introduction. In S. Buzawa (Ed.), Violence against women in families and relationships, victimization, and the community response (pp. vii-xviii). Santa Barbara, CA: Praeger.

Steiner, L. (1995). Would the real women's magazine please stand up ...for women. In C. M. Lout (Ed.), Women and media: Content, careers, criticism (pp. 99-110). Belmont, CA: Wadsworth.

Strauss, N. (2001, May). The ballad of Pam \& Tommy Lee and assorted other tales from the Motley Crue. Rolling Stone, 68, 54-64.

Tjaden, P. (2001). Extent and nature of intimate partner violence as measured by the National Violence Against Women Survey. Loyola Law Review, 47, 41-54.

Tjaden, P., \& Thoennes, N. (1998). Stalking in America: Findings from the National Violence Against Women Survey. Research in Brief. Washington, DC: U.S. Department of Justice, National Institute of Justice, NCJ 169592.

Tjaden, P., \& Thoennes, N. (2000a). Extent, nature, and consequences of intimate partner violence: Findings from the National Violence Against Women Survey. Research Report. Washington, DC: U.S. Department of Justice, NCJ 181867.

Tjaden, P., \& Thoennes, N. (2000b). Full report on prevalence, incidence, and consequences of violence against women: Findings from the National Violence Against Women Survey. Research Report. Washington, DC: U.S. Department of Justice, NCJ 183781.

Torneo, E. (2005a). Signs your spats are serious. Cosmopolitan, 238(5), 183. Torneo, E. (2005b). When fights get physical. Cosmopolitan, 238(5), 182-183. Tuchman, G. (1978). Introduction: The symbolic annihilation of women by the mass media. In Hearth and home: Images of women in the mass media (pp. 3-38). New York, NY: Oxford University Press.

Vavrus, M. D. (2002). Domesticating patriarchy: Hegemonic masculinity and television's "Mr. Mom". Critical Studies in Media Communication, 19(3), 352-373.

Vigneri, S. (2000, May). Stats page. Men's Health, 15(4), 150.

Welch, L. (2007, October). You may think that domestic violence has nothing to do with you. Redbook, 209(4), 212.

Weston, L., \& Ruggiero, J. (1985-1986). The popular approach to women's health issues: A content analysis of women's magazines in the 1970s. Women and Health, 10(4), 47-62.

Willis, E. (1994). Villains \& victims: "Sexual correctness" and the repression of feminism. Salmagundi, 101-102, 68-78.

Winship, J. (1987). Inside women's magazines. London, England: Pandora. Wisner, C. L., Gilmer, T. P., Saltzman, L. E., \& Zink, T. M. (1999). Intimate partner violence against women: Do victims cost health plans more? Journal of Family Practice, 48(6), 429-443.

Women's Studies in Communication, Vol. 34, No. 2 (2011): pg. 139-160. DOI. This article is (C) Taylor \& Francis (Routledge) and permission has been granted for this version to appear in e-Publications@Marquette. Taylor \& Francis (Routledge) does not grant permission for this article to be further copied/distributed or hosted elsewhere without the express permission from Taylor \& Francis (Routledge). 
NOT THE PUBLISHED VERSION; this is the author's final, peer-reviewed manuscript. The published version may be accessed by following the link in the citation at the bottom of the page.

Wolf, N. (1992). The beauty myth. New York, NY: HarperCollins.

Zoellner, T. (2000, May). Femmes fatales! Men's Health, 15(4), 151-152.

Women's Studies in Communication, Vol. 34, No. 2 (2011): pg. 139-160. DOI. This article is (C) Taylor \& Francis (Routledge) and permission has been granted for this version to appear in e-Publications@Marquette. Taylor \& Francis (Routledge) does not grant permission for this article to be further copied/distributed or hosted elsewhere without the express permission from Taylor \& Francis (Routledge). 